\title{
Species interactions in pure and mixed-species stands of silver fir and European beech in Mediterranean mountains
}

\author{
Soraya Versace ${ }^{(1-2)}$, \\ Vittorio Garfì ${ }^{(1)}$, \\ Michele Dalponte ${ }^{(2)}$, \\ Mirko Di Febbraro ${ }^{(1)}$, \\ Lorenzo Frizzera ${ }^{(2)}$, \\ Damiano Gianelle ${ }^{(2-3)}$, \\ Roberto Tognetti ${ }^{(3-4)}$
}

\begin{abstract}
Interactions between tree species determine the dynamics of forest communities. Spatial and temporal changes in resource availability, variation in species composition and spatial distribution of trees may alter competitive interactions between species and, therefore, affect tree growth and forest productivity. In this study, we analyzed the intra and inter-specific interactions between European beech (Fagus sylvatica L.) and silver fir (Abies alba Mill.) in southern Italy (Molise and Calabria regions), and how these interactions affect basal area increments in mixed-species and pure stands. Results showed that intraspecific interactions have a negative effect on the basal area increment, both in pure and mixed-species stands of Molise and Calabria. Basal area increment was higher influenced by intra-specific interactions in pure stands than in mixed-species stands. Silver fir in Molise showed higher basal area increment in mixed-species stand, probably in relation with stand structure and space occupation that resulted in less competition between individual trees. European beech showed high values of intra-specific interactions in pure stands, likely related to the low self-tolerance of this species and to the spatial arrangement of trees, due to canopy closure. The absence of inter-specific interactions in mixed-species stands could be explained by the sub-dominant position of European beech, which may have limited the benefit derived from niche separation and complementarity for silver fir.
\end{abstract}

Keywords: Abies alba Mill., Fagus sylvatica L., Intra-specific Interactions, Inter-specific Interactions, Stand Productivity, Tree Growth ity and the most important drivers for the dynamics of forest communities.

Several studies have shown that higher tree species richness may lead to greater forest stand productivity (Vilà et al. 2013, Liang et al. 2016). Mixed-species stands showed higher degree of resistance and resilience to biotic and abiotic disturbances (Jactel \& Brockerhoff 2007, Seidl et al. 2016), and wider range of ecosystem services in comparison to corresponding monocultures (Gamfeldt et al. 2013). Nevertheless, further experimental insights on the ecosystem functions of mixed-species ble for the effects of niche complementar-

$\square$ (1) Department of Biosciences and Territory, University of Molise, c.da Fonte Lappone, 86090 Pesche, IS (Italy); (2) Department of Sustainable Agro-ecosystems and Bioresources, Research and Innovation Centre, Fondazione E. Mach, v. E. Mach 1, 38010 San Michele all'Adige, TN (Italy); (3) The EFI Project Centre on Mountain Forests (MOUNTFOR), v. Edmund Mach 1, 38010, San Michele all'Adige, TN (Italy); (4) Department of Agricultural, Environmental and Food Sciences, University of Molise, v. Francesco De Sanctis, 86100 Campobasso (Italy)

@ Soraya Versace (s.versace@studenti.unimol.it)

Received: Apr 20, 2020 - Accepted: Oct 26, 2020

Citation: Versace S, Garfì V, Dalponte M, Di Febbraro M, Frizzera L, Gianelle D, Tognetti R (2021). Species interactions in pure and mixed-species stands of silver fir and European beech in Mediterranean mountains. iForest 14: 1-11. - doi: 10.3832/ifor3476-013 [online 2021-01-02]

Communicated by: Giorgio Vacchiano stands and the ecological mechanisms that cause their over-yielding is required for implementing resource-efficient management strategies (Forrester 2014), particularly, in drought-prone environments (Grossiord et al. 2014, Conte et al. 2018). Indeed, under limited resource availability, as the number of individuals in a tree population tends to fill the available growing space and the density continues to increase, competition for water (besides nutrients and light) increases as well (Tognetti et al. 2007).

Interactions between individual trees in a forest stand can be studied and identified through the use of competition indices (Daniels 1976, Biging \& Dobbertin 1992, 1995). In mixed-species populations, in order to better understand the interactions that occur between tree species, a distinction between intra- and inter-specific competition indices is recommended (Del Río et al. 2014). Several studies have found that in presence of a reduction of competition or of a facilitating effect (Del Río et al. 2014) inter-specific interactions can advantage tree growth in mixed-species stands (Aussenac et al. 2019). Although in mixedspecies stands the interactions are often less severe than in the corresponding monocultures (Coates et al. 2013, Mölder \& Leuschner 2014), the positive effects of neighborhood complementarity on tree growth may depend on several factors, such as stand density (Condés et al. 2013), 
site quality (Pretzsch et al. 2010) and changes in growth conditions (Del Río et al. 2014). It must be pointed out, however, that distinguishing between competition reduction and facilitation effect is almost impossible and, therefore, these two processes are often defined as complementarity (Forrester \& Bauhus 2016, Ammer 2019).

Competitive interactions between tree species, but also complementarity effects, may occur above- and/or below-ground. In forests with tree species that differ intrinsically in crown architecture and leaf phenology (e.g., deciduous vs. evergreen species, conifers vs. broadleaved trees), speciesspecific occupation of the growing space and partition of the intercepted radiation may play a major role in the use of complementary resources (Forrester \& Albrecht 2014, Pretzsch et al. 2014). Moreover, in mixed-species stands, with shade-tolerant species and a heterogeneous spatial structure, the use of limiting resources (e.g., light) can be more efficient, since the trees in the dominated plane may take advantage of irradiance transmitted through the crown of the dominant trees, so as to survive and grow (Pretzsch 2014, Lu et al. 2016). Further, also co-occurrence of species that differ in their root architecture may improve the uptake of nutrients and water (Brassard et al. 2013). Below-ground competition does not only consider the interactions between dominant or/and subdominant trees with the subject tree, but also those trees whose roots occupy the root distribution area of the subject tree (Bošela et al. 2015). For example, silver fir (Abies alba Mill.) develops a deeper root system than European beech (Fagus sylvatica L.) and adopts a strategy that allows the absorption of water during the grow- ing season, namely in periods of high drought stress (Toïgo et al. 2015). Speciesspecific root uptake, but also capacity stomatal adjustment, may affect the hydraulic redistribution of soil water, particularly in drought-prone Mediterranean environments. Though unclear distinction between silver fir and European beech in the sensitivity of stomatal conductance to water potential has been reported (Klein 2014), silver fir promptly closes the stomata to maintain leaf water potential during drought events (i.e., isohydric behavior Magh et al. 2019). European beech, instead, continues to transpire even when soil water content diminishes (i.e., anisohydric behavior - Magh et al. 2019).

European beech has been often studied mixed with the comparatively drought-intolerant Norway spruce (Picea abies Karst. - Pretzsch \& Schütze 2009) or drought-tolerant Scots pine (Pinus sylvestris L. - Conte et al. 2018). However, mixed-species forests that include silver fir and European beech have recently earned attention and praise among forest researchers (Del Río et al. 2014, Bošela et al. 2015, Pretzsch \& Biber 2016). Renewed interest for silver fir can be related to recent findings of enhanced productivity of silver fir in central Europe (Bošela et al. 2014) and to the relatively high drought tolerance of this species, particularly in southern Italy and mountain environments (Antonucci et al. 2019). Silver fir has a geographical distribution similar to that of European beech, though restricted to mountain ranges, and grow well in the southernmost locations in the mountain ranges of Italy (Marziliano et al. 2019). Toward its southern distribution limit, silver fir can be competitive with European beech (moderately drought tolerant) and,

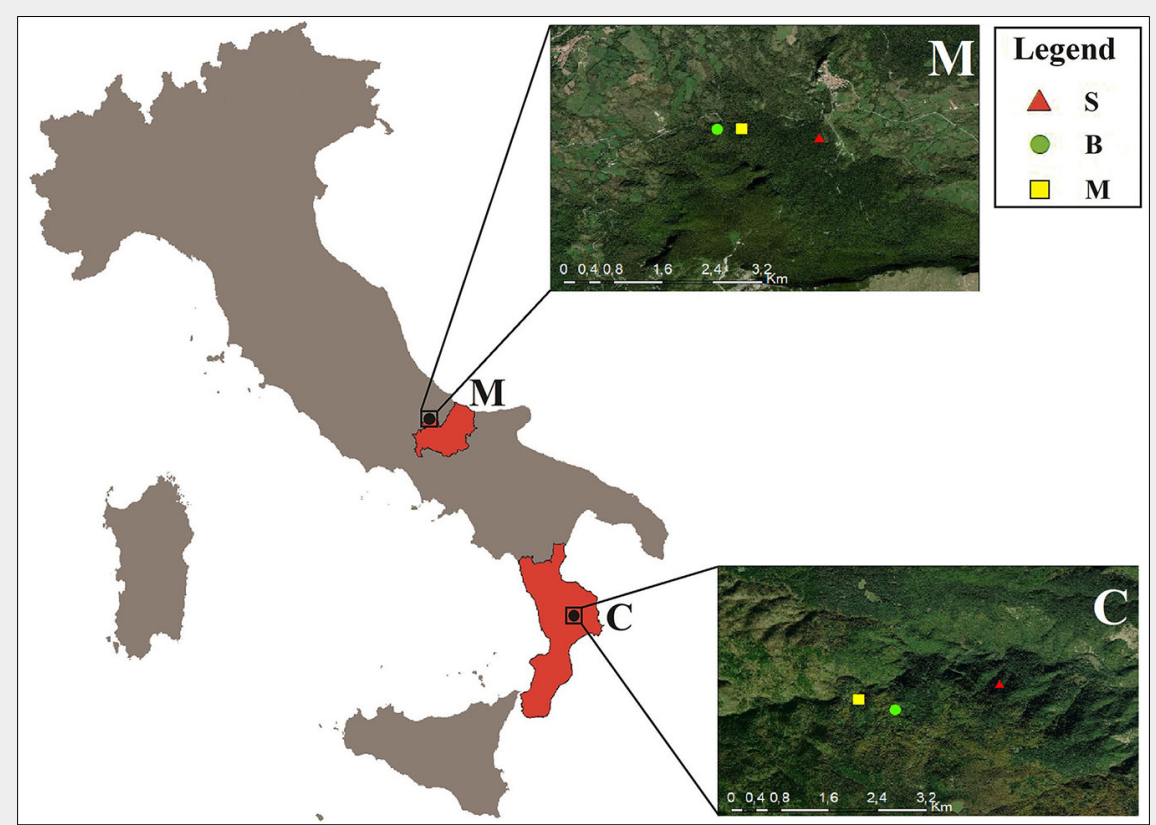

Fig. 1 - Location of the study sites in the southern Italy. Red triangle indicates silver fir in the pure stands (S); green circle indicates European beech in the pure stands (B); yellow square indicates the mixed-species stands $(M)$.

in central Europe, a good replacement for the more drought-sensitive Norway spruce at higher elevations (Schwarz \& Bauhus 2019).

This study aimed to analyze intra- and inter-specific interactions between European beech and silver fir, and the influence these interactions may have on the growth of trees in mixed-species stands and corresponding pure stands. In order to better understand the interactions between these two major forest species, we used competition indices at the individual tree level. Individual competition indices reflect the local density of the competitors, which interact with the reference tree (Tomé \& Burkhart 1989), giving the possibility to quantify the influence of neighboring individuals on the growth of the reference tree. We hypothesized that: (i) intra-specific competition is higher in pure stands than in mixedspecies stands; and (ii) tree species mixing and stand structural complexity mitigate the negative effect of inter-specific interaction.

\section{Materials and methods}

\section{Study sites}

The study sites included two triplets located in southern Italy (Molise and Calabria regions). In particular, the following forest sites were sampled: (i) "Abeti Soprani" (Molise) and (ii) Sila National Park ("Sila Piccola", Calabria - Fig. 1).

Each triplet is composed of three rectangular stands, including two pure stands of silver fir and European beech, and one mixed-species stand of these species. Stand size varied between 0.12 and 0.28 ha. Stands were selected according to the minimum number of individuals ( $\geq 50$ trees of silver fir and/or European beech per stand) and on the elevation range $(<250 \mathrm{~m}$ between the triplets). Furthermore, mixed and pure stands were identified on the basis of the basal area occupied by the tree species investigated inside the stand, according to the classification of Mina et al. (2018a). Stands were considered pure when the basal area of the studied tree species was at least $85 \%$. Mixed-species stands, on the other hand, were classified as a mixture of the two species when, both species represented $85 \%$ or more of the total basal area and each of the two species contributed at least $20 \%$ of the basal area (Tab. 1). The horizontal structure was different in the two regions. Stands in Molise showed a random spatial arrangement of the trees, while in Calabria the structure was mainly clustered (Fig. 2).

Stands have similar exposure (North, North-West) and slope, between $20^{\circ}$ and $28^{\circ}$, except for pure stand of silver fir in Calabria $\left(37^{\circ}\right)$, but differ for soil type and depth. In Molise, the main soil type is Rendzina, whereas in Calabria is Distrudept. Soils in pure stands of European beech are relatively shallow and rocky in comparison with those of the mixed-species stands and 
Tab. 1 - Location of the study sites and structural parameters in the pure and mixed-species stands of European beech and silver fir in Molise and Calabria. (BA): stand basal area; (BAs): basal area percentage of the main species; $\left(\mathrm{d}_{\mathrm{g}}\right)$ : quadratic mean diameter; $\left(\mathrm{h}_{\mathrm{g}}\right)$ : quadratic mean height.

\begin{tabular}{|c|c|c|c|c|c|c|c|c|}
\hline \multirow{2}{*}{$\begin{array}{l}\text { Stand } \\
\text { Characteristics }\end{array}$} & \multicolumn{4}{|l|}{ Molise } & \multicolumn{4}{|l|}{ Calabria } \\
\hline & beech $_{\text {pure }}$ & fir $_{\text {pure }}$ & beech $_{\text {mixed }}$ & $\mathrm{fir}_{\text {mixed }}$ & beech $_{\text {pure }}$ & fir $_{\text {pure }}$ & beech $_{\text {mixed }}$ & $\mathrm{fir}_{\text {mixed }}$ \\
\hline Latitude $(\mathrm{N})$ & $41^{\circ} 52^{\prime} 13.65^{\prime \prime}$ & $41^{\circ} 52^{\prime} 11.02^{\prime \prime}$ & \multicolumn{2}{|c|}{$41^{\circ} 52^{\prime} 14.35^{\prime \prime}$} & $39^{\circ} 09^{\prime} 13.49^{\prime \prime}$ & $39^{\circ} 09^{\prime} 19.31^{\prime \prime}$ & \multicolumn{2}{|c|}{$39^{\circ} 09^{\prime} 07.96^{\prime \prime}$} \\
\hline Longitude $(\mathrm{E})$ & $14^{\circ} 16^{\prime} 37.85^{\prime \prime}$ & $14^{\circ} 17^{\prime} 26.03^{\prime \prime}$ & \multicolumn{2}{|c|}{$14^{\circ} 16^{\prime} 51.26^{\prime \prime}$} & $16^{\circ} 39^{\prime} 53.05^{\prime \prime}$ & $16^{\circ} 41^{\prime} 2.30^{\prime \prime}$ & \multicolumn{2}{|c|}{$16^{\circ} 40^{\prime} 12.33^{\prime \prime}$} \\
\hline Aspect $\left({ }^{\circ}\right)$ & 354 & 317 & 327 & - & 343 & 319 & 307 & - \\
\hline Altitude (m a.s.l.) & 1182 & 1230 & 1182 & - & 1289 & 1220 & 1332 & - \\
\hline Slope $\left({ }^{\circ}\right)$ & 21 & 20 & 27 & - & 24 & 37 & 28 & - \\
\hline $\mathrm{BA}\left(\mathrm{m}^{2} \mathrm{ha}^{-1}\right)$ & 33.6 & 54.4 & 45.2 & - & 59.7 & 61.5 & 74.6 & - \\
\hline BAs (\%) & 92 & 92 & 20 & 78 & 86 & 85 & 33 & 61 \\
\hline No. trees ha-1 & 989 & 486 & 134 & 202 & 641 & 750 & 293 & 293 \\
\hline$d_{g}(\mathrm{~cm})$ & 21 & 37 & 28 & 58 & 35 & 32 & 35 & 47 \\
\hline$h_{g}(m)$ & 15 & 21 & 19 & 27 & 22 & 21 & 22 & 27 \\
\hline Soil depth $(\mathrm{cm})$ & 20 & 50 & 40 & - & 50 & 70 & 90 & - \\
\hline
\end{tabular}

the pure stands of silver fir (Tab. 1). All triplets have not been thinned since 19791980.

\section{Field measurements}

At the beginning of summer 2017, the structural attributes and dendrometric parameters were determined in each stand, for all living trees with a diameter $\geq 7 \mathrm{~cm}$, through the Field-Map ${ }^{\circledR}$ technology and software (Institute of Forest Ecosystem Research Ltd. Jílové u Prahy, Czech Republic - http://www.fieldmap.cz/). For each tree, the stem diameter at $1.30 \mathrm{~m}$, the tree height, the crown radius in the four cardinal directions, the tree species, and the spatial position were recorded. Cores were sampled only from dominant and sub-dominant trees of European beech and silver fir.

Two cores per tree were collected at breast height $(1.3 \mathrm{~m})$ perpendicularly to the slope, in order to avoid compression wood (for silver fir) and tension wood (for European beech). Ring-width series were mea- sured with a LINTAB measuring table with an accuracy of $0.01 \mathrm{~mm}$, equipped with a Leica $\mathrm{MS}^{\circledast}$ stereoscope (Leica Microsystems, Wetzlar, Germany). The analysis was performed with the TSAP software package (Rinn 2003) and subsequently were cross-dated using COFECHA (Holmes et al. 1986, Grissino-Mayer 2001) to assess the measurement and dating accuracy. We successfully cross-dated 526 cores in total.

The raw chronologies were converted into tree basal area increment (BAI), according to the following standard equation (eqn. 1):

$$
B A I=\pi\left(r_{t}^{2}-r_{t-1}^{2}\right)
$$

where $r$ is the radius of the tree and $t$ is the year of tree-ring formation.

\section{ndividual-based competition indices}

To analyze the competitive dynamics within the stands, we used distance-dependent competition indices. Generally, although not for stands with stationary structures (Weiskittel et al. 2011), these indices are considered useful for explaining competitive interactions between individual trees (Stadt et al. 2007). Distance-dependent indices, in addition to the individual tree sizes, may also provide spatial information on the competitive status of an individual tree (Wang et al. 2012).

To calculate the distance-dependent indices, several methods can be applied (Hegyi 1974, Daniels et al. 1986, Tomé \& Burkhart 1989). Three distance-dependent competition indices $(\mathrm{Cl})$ based on stem diameter at breast height (DBH) were used in this study: Hegyi (1974 - eqn. 2), Martin \& Ek (1984 - eqn. 3) and Rouvinen \& Kuuluvainen (1997 - eqn. 4).

The competition indices were calculated using the following formulas:

$$
\begin{aligned}
C I_{\text {Hеg }} & =\sum_{j=1}^{n} \frac{D B H_{j} / D B H_{i}}{\text { dist }_{i j}+1} \\
C I_{\text {ME }} & =\sum_{j=1}^{n}\left[\frac{D B H_{j}}{D B H_{i}} \cdot e^{-\left(\frac{1 \text { dist }_{i j}}{D B H_{i}+D B H_{j}}\right)}\right]
\end{aligned}
$$

Fig. 2 - Spatial arrangement of trees in pure and mixedspecies stands in Molise (A: silver fir; B: European beech; C: mixed-species) and in Calabria (D: silver fir; E: European beech; F: mixed-species). Green indicate silver fir and violet European beech. A different colour is assigned to each species (minor species included).

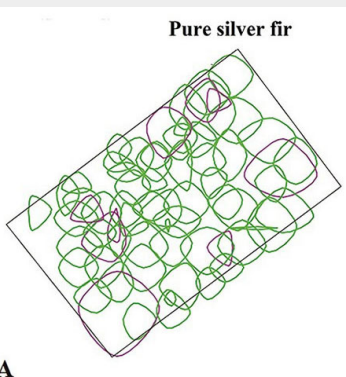

$A$

Pure silver fir

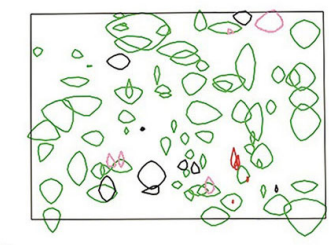

D

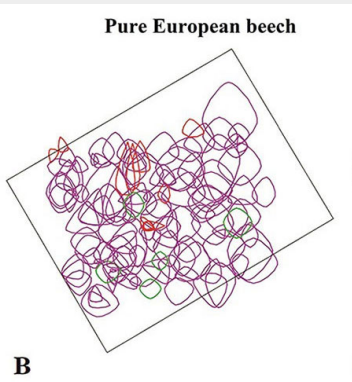

Pure European beech

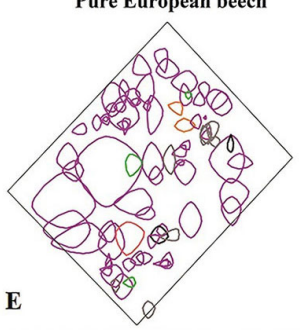

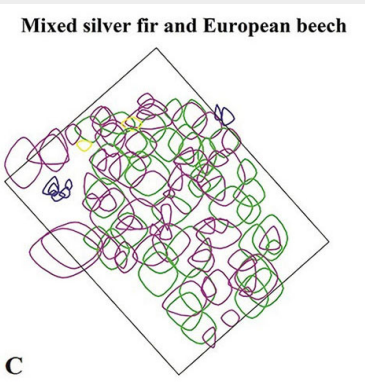

Molise

Legend

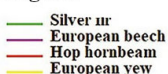

二 $\begin{gathered}\text { European beect } \\ \text { Hop hornbeam }\end{gathered}$

Sycamore map
Mixed silver fir and European beech

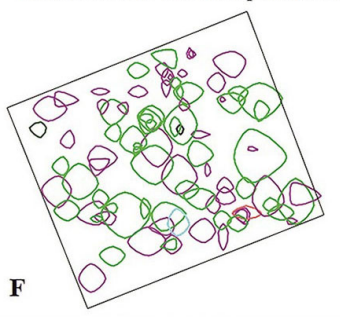

Calabria

Legend - Silver fir - Iurkey oak - Aspen
Hop hornbeam
European black pine Europea
Elm
Einden 


$$
C I_{R K}=\sum_{j=1}^{n} \frac{D B H_{j} / D B H_{i}}{\left(\text { dist }_{i j}\right)^{2}}
$$

(4)

In the above equations, $\mathrm{DBH}_{\mathrm{i}}$ is the diame ter at breast height of the subject tree $i$, $\mathrm{DBH}_{\mathrm{j}}$ the diameter at breast height of the competitor tree $j$, dist ${ }_{i j}$ the distance between the subject tree $i$ and the competitor tree $j$, and $n$ is the number of competitors in the neighborhood zone.

In order to calculate the competition indices only European beech and silver fir were considered, being the overwhelming species in the sampled stands. The competition indices were calculated at the beginning of the growing period (2011), which allowed us to build the mixed model (see below). In order to obtain the DBHs for 2011, the basal area increments of all European beech and silver fir trees in mixed-species and pure stands were reconstructed. In detail, basal area increments in the last 5 years (2011-2016) and the thickness of the bark (in some cores also the beginning of growth in 2017) of all cored trees were considered. The 5-year basal area increment $\left(\mathrm{BAl}_{\text {5years }}\right)$ and bark thickness were adapted to DBH measured in 2017 of cored trees, using linear models for each site and each species. This allowed to estimate the 5-year basal area increment $\left(\mathrm{BAl}_{5 \text { years }}\right)$ and the bark thickness of non-cored trees, and values were sequentially subtracted from the DBH measured in 2017 to reconstruct DBH in 2011 of non-cored European beech and silver fir trees.

The selection of competitors was determined by the fixed radius method. The competition indices $(\mathrm{Cl})$ values were obtained using neighborhood radii ranging 1$10 \mathrm{~m}$ (in $1 \mathrm{~m}$ increments) from the subject tree. Linear regression models were used to identify the optimal search radius and the corresponding $\mathrm{Cl}$ was used in the subsequent analyses. Linear regression models were tested and evaluated on the basis of the constancy of variances ( $p>0.05)$, adjusted $r^{2}$, and significance of the correlation $(p<0.1)$. The $\mathrm{BAl}_{5 \text { years }} \mathrm{Cl}$ relationship for silver fir trees was calculated only for trees with $\mathrm{DBH} \geq 20 \mathrm{~cm}$, given that the cored trees had a $\mathrm{DBH} \geq 20 \mathrm{~cm}$. European beech trees, however, had both a DBH $<20 \mathrm{~cm}$ and $\mathrm{DBH} \geq 20 \mathrm{~cm}$. Therefore, to assess whether the optimal search radius in European beech varied between the considered $\mathrm{DBH}$ values, the $\mathrm{BAI}_{5 y \text { ears }} \mathrm{Cl}$ relationship was calculated both for all cored trees $(20 \mathrm{~cm}>$ $\mathrm{DBH} \geq 20 \mathrm{~cm})$ and for cored trees with a $\mathrm{DBH} \geq 20 \mathrm{~cm}$ only.

For each tree, the $\mathrm{Cl}$ was divided into in ter-specific and intra-specific competition $\mathrm{Cl}$, when trees of different species from the focal tree species $\left(\mathrm{Cl}_{\text {inter }}\right)$ and trees of the focal species $\left(\mathrm{Cl}_{\text {intra }}\right)$ were considered, respectively.

\section{Modelling approach}

To investigate the effects of competitive interactions between mixed-species and pure stands, a mixed-effects model was ap- plied. Specifically, the basal area growth of the individual trees $\left(\mathrm{cm}^{2}\right.$ year-1) was chosen as the dependent variable, being less influenced by the age of the tree than the ringwidth time series (Biondi 1999). A natural logarithmic transformation of the original dependent variable was performed, usually being one of the best variables reflecting the non-linear tree growth curve (Wykoff 1990).

In the model, we considered the hypothesis that the basal area increment of the subject tree is a function of the tree size (SIZE), of the competition (COMP), of site characteristics (SITE), and of species in admixture (MIXTURE - eqn. 5):

$$
\begin{aligned}
\ln \left(B_{5 \text { years }}\right) & =a+b \text { SIZE }+c \text { COMP } \\
& +d \text { SITE }+e \text { MIXTURE }
\end{aligned}
$$

where the dependent variable is the 5-year basal area increment $\left(\mathrm{BAl}_{5 y \text { ears }}, \mathrm{cm}^{2}\right)$. The four independent variables were defined as (eqn. 6 to eqn. 9):

$$
S I Z E=b_{1} \ln (D B H)+b_{2} D B H^{2}+b_{3}\left(\frac{1}{A g e}\right)
$$

where the variable $\mathrm{DBH}(\mathrm{cm})$ is that measured at the beginning of the growing period (2011), and Age is the tree age in the year 2011;

$$
\begin{aligned}
C O M P & =c_{1} C I_{\text {intra }}+c_{2} C I_{\text {inter }} \\
& +c_{3} \text { mix }- \text { pure }
\end{aligned}
$$

where the competition variables are the intra-specific $\left(\mathrm{Cl}_{\text {intra }}\right)$ and inter-specific $\left(\mathrm{Cl}_{\text {inter }}\right)$ competition indices calculated at the beginning of the growing period (2011) of European beech and silver fir trees in mixedspecies and pure stands; mix-pure is the dummy variable, with mix-pure $=0$ for pure species stands and mix-pure $=1$ for mixedspecies stands;

$$
S I T E=d_{1} A L T+d_{2} S L O P E+d_{3} D E P T H
$$

where the site variables are topographic features of the stand, including elevation $(A L T)$, and slope and depth of the soil;

$$
\text { MIXTURE }=e_{1} B A_{\text {beech }}+e_{2} B A_{\text {fir }}
$$

where $B A_{\text {beech }}$ and $B A_{\text {fir }}$ are the basal area (measured at the beginning of the growing period - 2011) of European beech and silver fir, respectively.

The models (silver fir mixed-pure and European beech mixed-pure) were developed with competition variables conveying intraand inter-specific species interactions. The models for silver fir in mixed-species and pure stands were built with 55 trees, while the models for European beech in mixedspecies and pure stands were built with 50 trees. To test whether there was variability in the basal area increment between stands, we fitted a linear mixed model, including the stand (intercept) as a random effect.

Prior to fit the models through the "Imer" function of the R package "Ime4"
(Bates et al. 2014), the incidence of multicollinearity between the independent variables was evaluated, with the "VIF" function of the R package "car" (Fox et al. 2012). The threshold used to assess multicollinearity was VIF $=2.5$ (Dormann et al. 2013). After sub-setting the independent variables according to multicollinearity, models were fitted through the likelihood criterion (ML - Pinheiro \& Bates 2000) and compared using the Akaike's information criterion (AIC - see Appendix 1 in Supplementary material). We discarded redundant explanatory variables through the "chisq.test" function of the standard "statistics" package in R. The best models were fitted using the limited maximum likelihood method (REML), with a significance threshold of $p<0.05$. Normality and homogeneity of the residuals of the final models were visually inspected by plotting the residuals against fitted values (Zuur et al. 2009 - see Fig. S1 in Supplementary material). Conditional $R^{2}$ was obtained through the "r.squared GLMM" function of the “MuMIn" package (Barton 2013).

\section{Statistical analyses}

The differences between mixed-species and pure stands, in terms of competition and basal area increment, were assessed through the analysis of variance (ANOVA). Analyses were performed for each stand to identify significant correlations between the competition indices calculated at the beginning of the growing period (inter- and intra-specific) and basal area increment. For multiple comparisons of subgroups of variables, Tukey's post-hoc test was performed. All statistical analyses were performed using the $\mathrm{R}$ software package (https://www.r-project.org).

\section{Results}

\section{Stand structure}

Stands showed differences both in tree age (Tab. 2) and stem diameter distribution (Fig. 3). Age differences were observed between Molise and Calabria, as generally younger trees were found in Calabria (Tab. 2).

Considering all the species in each stand, diameter distribution showed a negative exponential pattern in almost all sites, except for pure silver fir in Molise (Fig. 3). DBH had a continuous distribution, with a maximum value of $80 \mathrm{~cm}$, except for silver fir (maximum DBH of $60 \mathrm{~cm}-$ Fig. 3A) and European beech ( $40 \mathrm{~cm}$ - Fig. 3B) in pure stands, in Molise. Variation in tree height also showed differences between the stands in Molise and those in Calabria (Fig. S2 in Supplementary material). In Molise, trees of silver fir were taller than those of European beech. In Calabria, instead, only in mixed-species stand, trees of silver fir grew taller than those of European beech, the first species occupying the dominant layer while the second the sub-dominated layer. 
Selection of competition index and identification of optimal search radius

Among the competition indices that were tested, the Hegyi index $\left(\mathrm{Cl}_{\mathrm{Heg}}\right)$, based on the relationship between the stem radial diameters and the distances between the subject tree and the competitors, explained the highest proportion of variability in basal area increment (Tab. 3). The Martin and Ek index $\left(\mathrm{Cl}_{\mathrm{ME}}\right)$ was the second best, while the Rouvinen and Kuuluvainen $\left(C I_{R K}\right)$ was the least appropriate for these stands. $\mathrm{Cl}_{\text {Heg }}$ explained a high proportion of variability in basal area increment for European beech (up to $72 \%$ in mixed-species and pure stands) than for silver fir, except for European beech in mixed-species stand in Calabria (from $26 \%$ to $39 \%$ ).

The optimal search radii were selected according to the highest prediction accuracy of the linear regression models (i.e., constancy of variances, adjusted $r^{2}$, and significance of the correlation - Tab. 4) obtained from the selected competition index $\left(\mathrm{Cl}_{\mathrm{Heg}}\right)$. The optimal search radii varied according to the species and stands examined (Tab. 4). In Molise, the highest accuracies of the linear regression model for silver fir were reached for optimal search radii of $10 \mathrm{~m}$. In Calabria, silver fir in pure and mixed-species stands, however, reached the highest prediction accuracy of the linear regression model for an optimal search radius of $9 \mathrm{~m}$ and $8 \mathrm{~m}$, respectively.

Considering only trees with $\mathrm{DBH} \geq 20 \mathrm{~cm}$, in Molise the optimal search radius for European beech in pure and mixed-species stands was $7 \mathrm{~m}$ and $9 \mathrm{~m}$, respectively (Tab. 4). In Calabria, the optimal search radii for European beech in pure and mixed-species stands was $7 \mathrm{~m}$ and $5 \mathrm{~m}$, respectively (Tab.
Tab. 2 - Tree age (range), average diameter at breast height (DBH) of sampled trees, 5 -year basal area increment $\left(B A I_{5 y e a r s}\right)$ with the standard deviation (SD), and number of trees and cores used in the study.

\begin{tabular}{llcccc}
\hline Site & Stand & $\begin{array}{c}\text { Tree age } \\
(\mathbf{y r s})\end{array}$ & $\begin{array}{c}\text { DBH } \pm \text { SD } \\
(\mathbf{c m})\end{array}$ & $\begin{array}{c}B A I_{5_{\text {years }} \pm \text { SD }} \\
\left(\mathrm{cm}^{2} \mathbf{y r}^{-1}\right)\end{array}$ & Cores/trees \\
\hline Molise & beech $_{\text {pure }}$ & $50-140$ & $22 \pm 6$ & $6.71 \pm 5.32$ & $110 / 60$ \\
& fir $_{\text {pure }}$ & $57-171$ & $42 \pm 8$ & $13.58 \pm 18.55$ & $86 / 44$ \\
& beech $_{\text {mixed }}$ & $50-119$ & $27 \pm 11$ & $17.26 \pm 17.32$ & $46 / 31$ \\
& fir $_{\text {mixed }}$ & $76-161$ & $59 \pm 14$ & $31.24 \pm 18.26$ & $38 / 19$ \\
\hline \multirow{3}{*}{ Calabria } & beech $_{\text {pure }}$ & $50-109$ & $41 \pm 15$ & $13.21 \pm 13.35$ & $78 / 46$ \\
& fir $_{\text {pure }}$ & $39-82$ & $37 \pm 12$ & $15.57 \pm 14.52$ & $82 / 43$ \\
& beech $_{\text {mixed }}$ & $53-128$ & $40 \pm 14$ & $14.53 \pm 14.45$ & $38 / 25$ \\
& fir $_{\text {mixed }}$ & $51-108$ & $52 \pm 16$ & $27.53 \pm 17.12$ & $46 / 28$ \\
\hline
\end{tabular}

Tab. 3 - Range of $R^{2}$ calculated for relationships between the 5-years basal area increment $\left(\mathrm{BAl}_{5 \text { years }}\right)$ of species and individual competition indices. $\left(\mathrm{Cl}_{\mathrm{Heg}}\right)$ : Hegyi index; $\left(C I_{M E}\right)$ : Martin and Ek index; $\left(C I_{R K}\right)$ : Rouvinen and Kuuluvainen index.

\begin{tabular}{llcccc}
\hline Site & $\begin{array}{l}\text { Competition } \\
\text { Index }\end{array}$ & fir $_{\text {pure }}$ & beech $_{\text {pure }}$ & fir $_{\text {mixed }}$ & beech $_{\text {mixed }}$ \\
\hline Molise & $\mathrm{Cl}_{\mathrm{Heg}}$ & $0.15-0.40$ & $0.08-0.50$ & $0.16-0.47$ & $0.44-0.72$ \\
& $\mathrm{Cl}_{\mathrm{ME}}$ & $0.05-0.39$ & $0.00-0.41$ & $0.14-0.40$ & $0.28-0.63$ \\
& $\mathrm{Cl}_{\mathrm{RK}}$ & $0.03-0.21$ & $0.00-0.20$ & $0.01-0.19$ & $0.02-0.14$ \\
\multirow{2}{*}{ Calabria } & $\mathrm{Cl}_{\mathrm{Heg}}$ & $0.12-0.45$ & $0.29-0.58$ & $0.00-0.53$ & $0.26-0.39$ \\
& $\mathrm{Cl}_{\mathrm{ME}}$ & $0.03-0.44$ & $0.13-0.21$ & $0.00-0.39$ & $0.08-0-33$ \\
& $\mathrm{Cl}_{\mathrm{RK}}$ & $0.00-0.43$ & $0.04-0.08$ & $0.01-0.20$ & $0.00-0.03$ \\
\hline
\end{tabular}

4). The same optimal search radii were identified also for all sampled trees inside the stand (Tab. S1).

Individual-level competition and BAI of mixed-species vs. pure stands

Tab. 5 shows the competition indices $\left(\mathrm{Cl}_{\mathrm{Heg}}\right)$ and the 5-years basal area increment calculated for each stand. Both intra-specific $\left(\mathrm{Cl}_{2011}\right.$ intra $)$ and inter-specific $\left(\mathrm{Cl}_{2011}\right.$ inter) indices showed higher levels of competition in pure stands of Molise than in pure stands of Calabria. European beech in mixed-species stands had higher values of intra- and inter-specific competition in Molise $(0.44 \pm 0.25$ and $0.99 \pm 0.32$, respec-
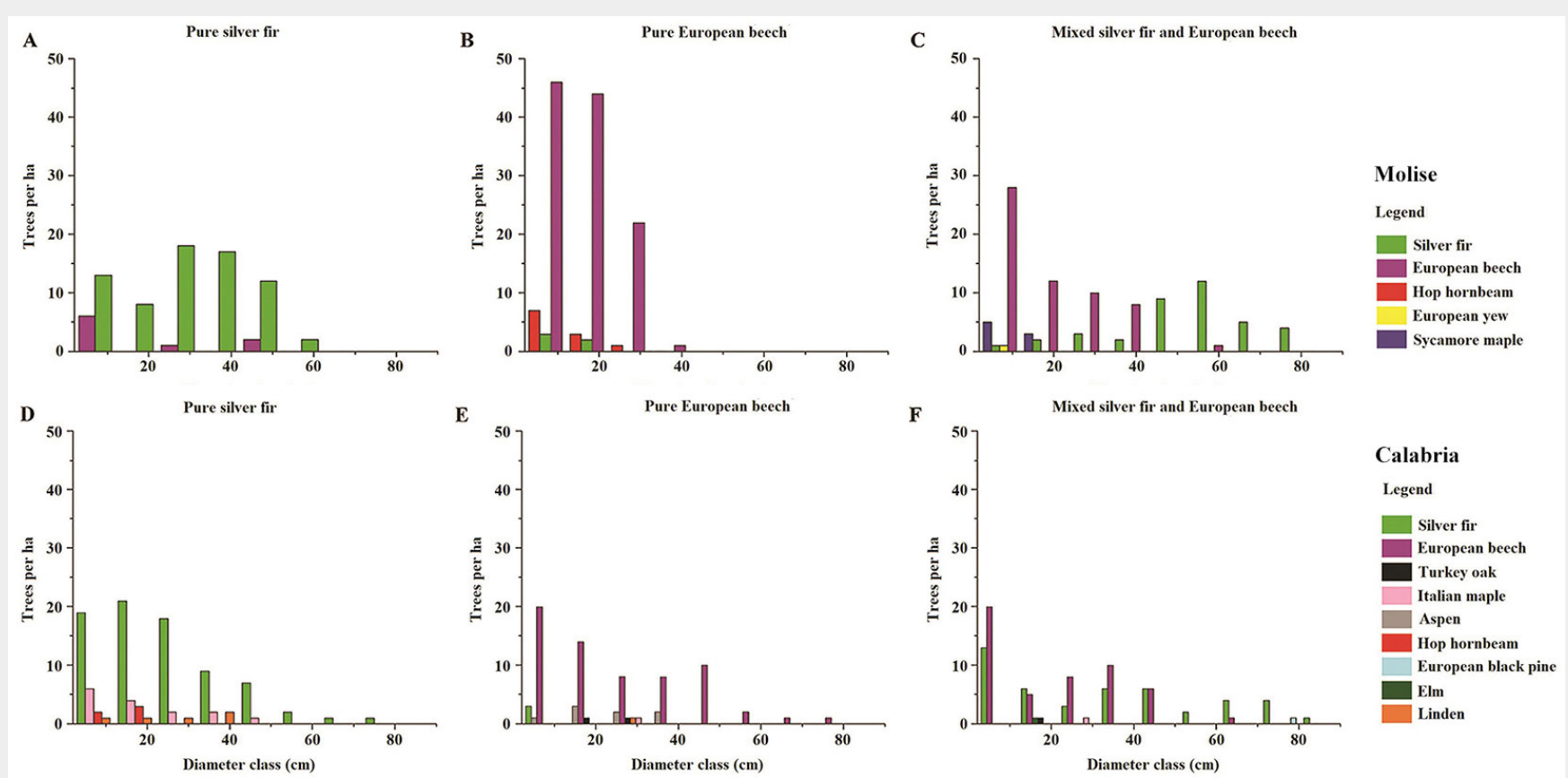

Fig. 3 - DBH distribution classes of all species in pure and mixed-species stands in Molise (A: silver fir; B: European beech; C: mixedspecies) and in Calabria (D: silver fir; E: European beech; F: mixed-species). The size of DBH classes was $10 \mathrm{~cm}$ both in pure and mixed-species stands. Tree species are referred to by colours in the legend. 
Tab. 4 - Optimal search radii selected on the basis of the best values of linear regres sion models, considering DBH $\geq 20 \mathrm{~cm}$. (CV): Constancy of variances $(p>0.05) ;\left(r^{2}\right)$ : adjusted $r^{2} ;(p)$ : significance of the correlation $(p<0.1)$; $(n)$ : number of tree samples; $R$ $(\mathrm{m})$ : optimal radius.

\begin{tabular}{|c|c|c|c|c|c|c|}
\hline Sites & Stands & $\mathrm{CV}$ & $r^{2}$ & $p$ & $n$ & $R(m)$ \\
\hline \multirow[t]{4}{*}{ Molise } & beech $_{\text {pure }}$ & 0.80 & 0.47 & $<0.01$ & 22 & 7 \\
\hline & fir $_{\text {pure }}$ & 1.76 & 0.36 & $<0.01$ & 18 & 10 \\
\hline & beech $_{\text {mixed }}$ & 0.13 & 0.69 & $<0.01$ & 13 & 9 \\
\hline & $\mathrm{fir}_{\text {mixed }}$ & 0.45 & 0.43 & $<0.01$ & 17 & 10 \\
\hline \multirow[t]{4}{*}{ Calabria } & beech $_{\text {pure }}$ & 0.78 & 0.38 & 0.03 & 10 & 7 \\
\hline & $\mathrm{fir}_{\text {pure }}$ & 3.14 & 0.39 & $<0.01$ & 14 & 9 \\
\hline & beech $_{\text {mixed }}$ & 3.38 & 0.30 & 0.07 & 9 & 5 \\
\hline & $\mathrm{fir}_{\text {mixed }}$ & 1.12 & 0.46 & 0.02 & 9 & 8 \\
\hline
\end{tabular}

Tab. 5 - Intra- and inter-specific $\mathrm{Cl}_{\mathrm{Heg}}$ in the mixed-species stands for European beech and silver fir at the beginning of the growing period $\left(\mathrm{Cl}_{2011}\right.$ intra and $\mathrm{Cl}_{2011}$ inter $)$ and basal area increment of the last 5 years $\left(B A I_{5 y e a r s}\right)$ for the analyzed species.

\begin{tabular}{llllc}
\hline Site & Stand & $C l_{2011 \_ \text {intra }}$ & $C l_{\text {2011_inter }}$ & $\begin{array}{c}B A I_{\text {5years }} \\
\left(\mathrm{cm}^{2} \mathrm{yr}^{-1}\right)\end{array}$ \\
\hline Molise & beech $_{\text {pure }}$ & $1.83 \pm 0.57$ & $0.09 \pm 0.14$ & $8.57 \pm 4.59$ \\
& fir $_{\text {pure }}$ & $1.89 \pm 0.57$ & $0.10 \pm 0.12$ & $10.12 \pm 8.13$ \\
\cline { 2 - 5 } & beech $_{\text {mixed }}$ & $0.44 \pm 0.25$ & $0.99 \pm 0.32$ & $19.52 \pm 10.93$ \\
\cline { 2 - 5 } Calabria & fir $_{\text {mixed }}$ & $0.49 \pm 0.39$ & $0.34 \pm 0.11$ & $33.10 \pm 19.55$ \\
& beech $_{\text {pure }}$ & $0.79 \pm 0.54$ & $0.02 \pm 0.02$ & $22.98 \pm 13.01$ \\
& fir $_{\text {pure }}$ & $1.94 \pm 0.47$ & 0 & $14.23 \pm 9.42$ \\
\cline { 2 - 5 } & beech $_{\text {mixed }}$ & $0.30 \pm 0.33$ & $0.48 \pm 0.35$ & $17.13 \pm 17.36$ \\
& fir $_{\text {mixed }}$ & $0.83 \pm 0.43$ & $0.49 \pm 0.26$ & $28.13 \pm 17.17$ \\
\hline
\end{tabular}

tively) than in Calabria (0.30 \pm 0.33 and $0.48 \pm 0.35$, respectively). In contrast, silver fir in mixed-species stands showed higher values of intra- and inter-specific competition in Calabria ( $0.83 \pm 0.43$ and $0.49 \pm$ 0.26 , respectively) than in Molise ( $0.49 \pm$ 0.39 and $0.34 \pm 0.11$, respectively).

The 5-years basal area increment $\left(\mathrm{BAl}_{5 \text { years }}\right)$ in pure stands was higher in Calabria than in Molise. Silver fir (33.10 \pm 19.55$)$ and European beech $(19.52 \pm 10.93)$ in mixed-species stands of Molise showed higher $\mathrm{BAI}_{5 \text { years }}$ values than in pure stands. In $\mathrm{Ca}$ labria, instead, only silver fir in mixed-species stand $(28.13 \pm 17.17)$ had higher $B A I_{\text {syears }}$ values than in pure stand $(14.23 \pm 9.42)$.

\section{Growth models}

The selection of the best intra-specific and inter-specific interaction models was based on the lowest values of AIC (Tab. S2 and Tab. $S_{3}$ in Supplementary material).

\section{Intra-specific interactions models}

The best intra-specific interaction models for silver fir mixed-pure, four independent variables were used: $\mathrm{Cl}_{2011}$ intra, slope, $\mathrm{DBH}^{2}$ and mix-pure (Tab. S4). In the model for European beech mixed-pure, six independent variables were used: $\mathrm{Cl}_{2011}$ intra, $\mathrm{BA}_{\text {beech, }}$ age, soil depth, $\mathrm{DBH}^{2}$ and mix-pure (Tab. S4). In the final model for silver fir mixedpure, only $\mathrm{Cl}_{2011}$ intra affected the basal area increment significantly (Tab. 6); the basal area increment decreased with increasing $\mathrm{Cl}_{2011}$ intra. Furthermore, the model showed differences between stands, with $R^{2}$ of 0.51 , when all effects were included, and $R^{2}$ of 0.50 , when only fixed effects were considered.

In the final model for European beech mixed-pure, $\mathrm{Cl}_{2011}$ intra, $\mathrm{DBH}^{2}$ and Soil depth affected the basal area increment significantly (Tab. 6); the basal area increment decreased with increasing $\mathrm{Cl}_{2011}$ intra and Soil depth. $\mathrm{DBH}^{2}$ showed direct responses to basal area increment. Furthermore, the model did not show differences between stands, with an $R^{2}$ of 0.60 , both when all effects were included and if only fixed effects were considered.

Basal area increment ( $\left.B A I_{\text {syears }}\right)$ revealed that only silver fir in mixed-species stand of Molise differed significantly from the corresponding pure stand ( $p<0.05-$ Fig. $4 A)$. In both Molise and Calabria, the basal area increments of European beech did not show significant differences between mixed-species and pure stands (Fig. 5A). The competition indices $\left(\mathrm{Cl}_{2011}\right.$ intra), on the other hand, differed significantly between pure and mixed-species stands of Molise and Calabria ( $\mathrm{p}<0.05$ - Fig. 4B, Fig. 5B). In Molise and Calabria, silver fir in mixedspecies stands differed significantly from silver fir in pure stands ( $\mathrm{p}<0.05$ - Fig. 4B). Values of $\mathrm{Cl}_{2011}$ intra were higher in mixedspecies and pure stands of European beech in Molise than in Calabria (Fig. 5B).

\section{Inter-specific interactions models}

Even for inter-specific interactions, the best models for silver fir mixed-pure, four independent variables were used: $\mathrm{Cl}_{2011}$ in ter, slope, $\mathrm{DBH}^{2}$ and mix-pure (Tab. S5). In the model for European beech mixed-pure, six independent variables were used: $\mathrm{Cl}_{2011}$ inter, $\mathrm{BA}_{\text {beech, }}$ age, Soil depth, $\mathrm{DBH}^{2}$ and mix-pure (Tab. S5). In the final model for silver fir mixed-pure, only $\mathrm{DBH}^{2}$ significantly affected the basal area increment (Tab. 7). $\mathrm{DBH}^{2}$ showed direct responses to tree basal area increment. The model showed also differences between stands, with an $R^{2}$ of 0.46 , when all effects were included, and $R^{2}$ of 0.36 , when only fixed effects were considered.

Tab. 6 - Parameter estimates and fitting statistics for the best intra-specific interaction models through the limited maximum likeli hood method (REML). ( $\mathrm{Cl}_{2011}$ intra): intra-specific interactions; $\left(\mathrm{DBH}^{2}\right)$ : diameter at breast height squared ( $\left.\mathrm{cm}^{2}\right)$; (Soil depth): depth of the soil; $\left(\operatorname{Var}_{\text {Plot }}\right)$ : Plot (intercept) variance; $\left(\operatorname{Var}_{\text {Res }}\right)$ : Residual variance; (SD): standard deviation; (AIC); Akaike's information criterion (mixed effect).

\begin{tabular}{|c|c|c|c|c|c|c|c|c|c|}
\hline \multirow{2}{*}{$\begin{array}{l}\text { Stand } \\
\text { Type }\end{array}$} & \multicolumn{4}{|c|}{ Fixed effects } & \multicolumn{5}{|c|}{ Random effects } \\
\hline & Factor & Est. & SE & Prob. & $\begin{array}{l}\operatorname{Var}_{\text {Plot }} \\
\text { (SD) }\end{array}$ & $\begin{array}{l}\operatorname{Var}_{\text {Res }} \\
\text { (SD) }\end{array}$ & $R^{2} m$ & $R^{2} c$ & AIC \\
\hline $\begin{array}{l}\text { Silver fir } \\
\text { mixed-pure }\end{array}$ & $\mathrm{Cl}_{2011}$ intra & -0.693 & 0.102 & $<0.001$ & $\begin{array}{c}0.011 \\
(0.106)\end{array}$ & $\begin{array}{c}0.465 \\
(0.682)\end{array}$ & 0.500 & 0.510 & 126.537 \\
\hline \multirow{3}{*}{$\begin{array}{l}\text { European } \\
\text { beech } \\
\text { mixed-pure }\end{array}$} & $\mathrm{Cl}_{2011 \_ \text {intra }}$ & -0.667 & 0.122 & $<0.001$ & \multirow{3}{*}{$\begin{array}{c}0.000 \\
(0.000)\end{array}$} & \multirow{3}{*}{$\begin{array}{l}0.513 \\
(0716)\end{array}$} & \multirow{3}{*}{0.600} & \multirow{3}{*}{0.600} & \multirow{3}{*}{147.014} \\
\hline & $D B H^{2}$ & 0.595 & 0.12 & $<0.001$ & & & & & \\
\hline & Soil_depth & -0.45 & 0.126 & $<0.001$ & & & & & \\
\hline
\end{tabular}


In the final model for European beech mixed-species and pure stands, $B A_{\text {beech, }}$ $\mathrm{DBH}^{2}$ and Soil depth affected the basal area increment significantly (Tab. 7); the basal area increment decreased with increasing $B A_{\text {beech }}$ and Soil_depth. $\mathrm{DBH}^{2}$ showed direct responses to basal area increment. The model did not show differences between stands, with an $R^{2}$ of 0.57 , both when all effects were included and if only fixed effects were considered.

\section{Discussion}

Influence of intra-specific interactions on trees basal area increment in mixedspecies and pure stands

We analyzed the effect of interactions between tree species on the basal area increment of uneven-aged mixed-species and pure stands of European beech and silver fir, implementing growth models and competition indices at the individual tree level. The final models showed strong influence of intra-specific interactions $\left(\mathrm{Cl}_{2011}\right.$ intra $)$ on the basal area increment $\left(B A I_{5 y \text { years }}\right)$ of both species (Tab. 6). The dummy variable mixpure (Tab. S4 in Supplementary material) indicates the influence of variables related to the pure and mixed-species stands on the basal area increment ( $\left.B A I_{5 y e a r s}\right)$. The absence of significance of this variable, suggests that intra-specific interactions ( $\mathrm{Cl}_{2011}$ intra) had high influence on the basal area increment $\left(B A I_{5 y e a r s}\right)$ of both species in mixed-species and pure stands. Therefore, European beech and silver fir in mixedspecies and pure stands were more affected by competition with conspecific than allospecific neighbors. Several studies indicated that European beech is a strong self-competitor (Pretzsch et al. 2010, 2013, Bošela et al. 2015), with high intra-specific competition for above-ground (Pretzsch \& Schutze 2016) and below-ground (Rewald \& Leuschner 2009, Del Río et al. 2014, Mina et al. 2018b) resources. In literature studies on silver fir focused mainly on drought response (Lebourgeois et al. 2013), while are rather scarce in terms of competitive interactions between mixed-species and pure stands.

Analysis of variance (ANOVA) showed

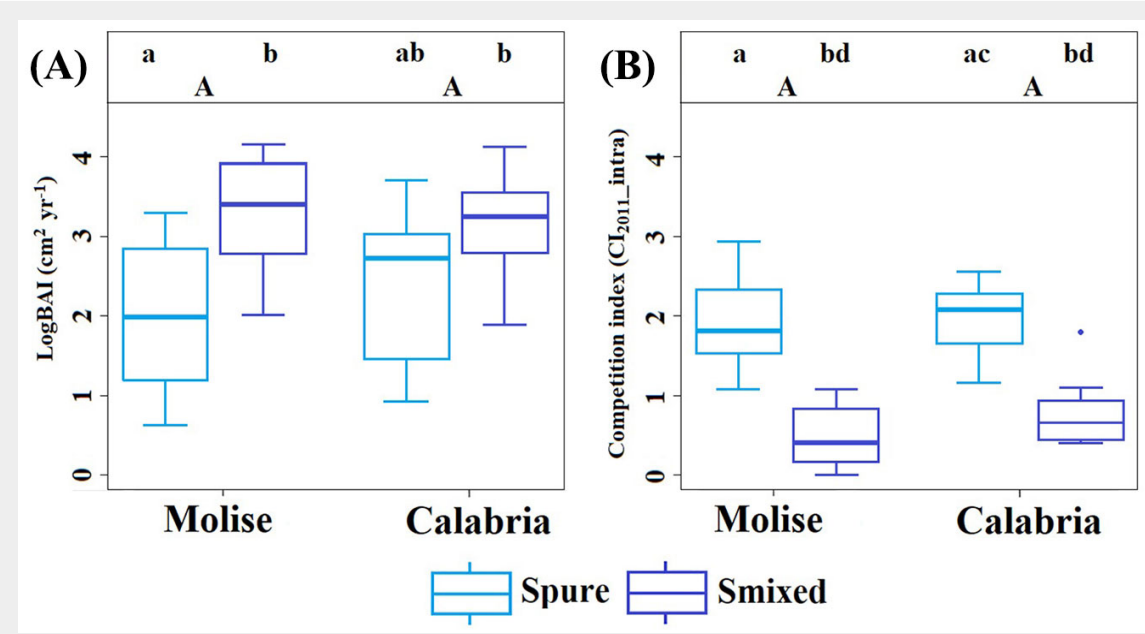

Fig. 4 - Basal area increment (logBAI) and competition indices $\left(\mathrm{Cl}_{2011}\right.$ intra) of silver fir in mixed-species and pure stands, considering the last 5 years and the beginning of the growing period. Smixed refers to mixed-species stands (Calabria and Molise) and Spure to pure stands (Calabria and Molise). Capital letters indicate differences between the sites for basal area increment and competition indices, and small letters indicate differences between species (ANOVA and post-hoc tests, $p<0.05$ ). The vertical lines represent the "whiskers" for the $5^{\text {th }}$ and $95^{\text {th }}$ percentiles of data distribution.

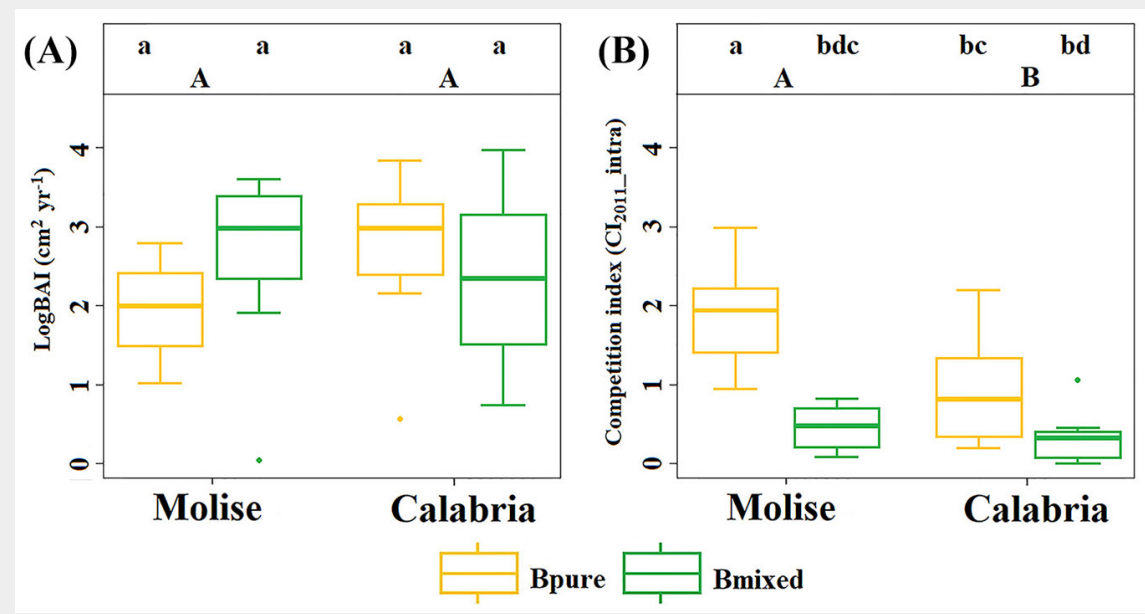

Fig. 5 - Basal area increment (logBAl) and competition indices $\left(\mathrm{Cl}_{2011}\right.$ intra $)$ of European beech in mixed-species and pure stands, considering the last 5 years and the beginning of the growing period. Bmixed refers to mixed-species stands (Calabria and Molise) and Bpure to pure stands (Calabria and Molise). Capital letters indicate differences between sites for each competition index, intra- and inter-specific (ANOVA and post-hoc tests, $\mathrm{p}<0.05)$. The vertical lines represent the "whiskers" for the $5^{\text {th }}$ and $95^{\text {th }}$ percentiles of data distribution.

Tab. 7 - Parameter estimates and fitting statistics for the best inter-specific interaction models through the limited maximum likelihood method (REML). (DBH'): diameter at breast height squared $\left(\mathrm{cm}^{2}\right)$; (Age): tree age (years); (Soil_depth): depth of the soil; $\left(B A_{\text {beech }}\right)$ : basal area occupied by competitors of European beech; $\left(\operatorname{Var}_{\text {Plot }}\right)$ : Plot (intercept) variance; $\left(\operatorname{Var}_{\text {Res }}\right)$ : Residual variance; (SD): standard deviation; (AIC); Akaike's information criterion (mixed effect).

\begin{tabular}{|c|c|c|c|c|c|c|c|c|c|}
\hline \multirow{2}{*}{$\begin{array}{l}\text { Stand } \\
\text { Type }\end{array}$} & \multicolumn{4}{|c|}{ Fixed effects } & \multicolumn{5}{|c|}{ Random effects } \\
\hline & Factor & Est. & SE & Prob. & $\begin{array}{l}\operatorname{Var}_{\text {Plot }} \\
\text { (SD) }\end{array}$ & $\begin{array}{l}\operatorname{Var}_{\text {Res }} \\
\text { (SD) }\end{array}$ & $\mathrm{R}^{2} \mathrm{~m}$ & $R^{2} c$ & AIC \\
\hline $\begin{array}{l}\text { Silver fir } \\
\text { mixed-pure }\end{array}$ & $D B H^{2}$ & 0.562 & 0.114 & $<0.001$ & $\begin{array}{c}0.093 \\
(0.305)\end{array}$ & $\begin{array}{c}0.479 \\
(0.692)\end{array}$ & 0.360 & 0.460 & 130.837 \\
\hline \multirow{4}{*}{$\begin{array}{l}\text { European } \\
\text { beech } \\
\text { mixed-pure }\end{array}$} & $D B H^{2}$ & 0.678 & 0.125 & $<0.001$ & \multirow{4}{*}{$\begin{array}{c}0.000 \\
(0.000)\end{array}$} & \multirow{4}{*}{$\begin{array}{c}0.564 \\
(0.751)\end{array}$} & \multirow{4}{*}{0.570} & \multirow{4}{*}{0.570} & \multirow{4}{*}{141.972} \\
\hline & Age & 0.192 & 0.113 & 0.097 & & & & & \\
\hline & Soil_depth & -0.456 & 0.135 & 0.001 & & & & & \\
\hline & $B A_{\text {beech }}$ & -0.541 & 0.122 & $<0.001$ & & & & & \\
\hline
\end{tabular}


that the influence of intra-specific interac tions $\left(\mathrm{Cl}_{2011}\right.$ intra $)$ was higher in pure stands of silver fir and European beech than in mixed-species stands (Fig. 4B, Fig. 5B), supporting our first hypothesis. In Molise, ANOVA highlighted significantly higher in crease in the basal area increment $\left(\mathrm{BAl}_{\text {syears }}\right)$ of silver fir in mixture than in monoculture (Fig. 4A). In accordance with our results, Toïgo et al. (2015) observed an increase in the basal area increment of silver fir more marked in mixed-species stands than in pure stands. Crown architecture, vertical positioning within the canopy and root morphology may lead to differences in resources accessibility between pure and mixed-species stands, and, therefore, a more efficient use of water and light (Linares et al. 2010, Forrester \& Bauhus 2016) However, in our case, higher basal area increments of silver fir trees in the mixedspecies stand in Molise, compared to the corresponding pure stand (Fig. 4A) might depend on differences in stand structure (Fig. 3). Silver fir trees in the mixed-species stand were bigger $(\mathrm{DBH}>50 \mathrm{~cm})$ than in the pure stand $(\mathrm{DBH}<50 \mathrm{~cm})$, which might explain the reduction in competitive interactions and, consequently the higher basal area increment of silver fir trees in the mixed-species stand.

European beech, instead, showed high tree-to-tree competition in pure stands, most probably related to the low self-tolerance of this species (Pretzsch 2006), which is attenuate in mixed-species stands (Pret zsch et al. 2012). For example, Mölder \& Leuschner (2014) found a lower impact of intra-specific interactions on the basal area increment of European beech in mixedspecies forests than in pure stands. This less negative impact of intra-specific interactions was related to the lower number of European beech trees among competitors, confirming that European beech is a strong self-competitor. High levels of intra-specific interactions may also depend on high degree of canopy closure in pure stands of European beech (Pretzsch et al. 2010). In our case, significantly higher intra-specific competition levels ( $\mathrm{Cl}_{2011}$ intra) were observed in pure stand of European beech, in Molise, which had closed canopy (Fig. 2B), in comparison with the corresponding one in Calabria (Fig. 2E). A closed-canopy may derive from different spatial arrangement of trees, random (in Molise) vs. clustered (in Calabria). In fact, mixed-species and pure stands of European beech showed higher influence of intra-specific interac tions $\left(\mathrm{Cl}_{2011}\right.$ intra $)$ in Molise than in Calabria (Fig. 5B). Gap recruitment of small compet ing trees leading to clustered regeneration may occur more frequently in drier sites (Spies et al. 1990). Edaphic heterogeneity and local aridity may also cause clumped spatial distribution of trees.

Several studies found that the stand-level spatial arrangement of trees may influence the competitive intensity between species (Fraver et al. 2014), especially in uneven- aged and uneven-structured stands (Weber et al. 2008), as well as in those stands with trees differing in crown morphology, crown efficiency and space occupation (Metz et al. 2013). This would suggest that the forest structure (e.g., spatial arrangement, crown morphology, etc.) may regulate tree-to-tree competition and tree growth in structurally diverse forests (Fraver et al. 2014).

\section{Intra- and inter-specific interactions in mixed-species stand}

Inter-specific interaction (Tab. 7), was not the most important variable to explain the competitive interactions in mixed stands. This suggests that inter-specific interactions $\left(\mathrm{Cl}_{2011}\right.$ inter) in mixed-species stands did not significantly influence the basal area increment, supporting our second hypothesis. Gazol et al. (2016) observed higher growth rates in silver fir admixed with European beech. Other studies of intra- and inter-specific interactions on firbeech mixtures indicated either no effects of mixing on basal area increment of either species (Del Río et al. 2014, Schwarz \& Bauhus 2019) or positive mixing effects for beech, whereas positive effects for silver fir could be restricted to sites of lower productivity (Toïgo et al. 2015). A negative influence of intra-specific interactions (in comparison with inter-specific interactions) on the growth of European beech was confirmed in the present study. However, the effect of these interactions on the growth of silver fir needs to be further explored, in view of contradicting results of previous studies (Del Río et al. 2014, Bošela et al. 2015, Mina et al. 2018b). Indeed, Mina et al. (2018b) found that the growth of silver fir was negatively affected by the presence of European beech. In contrast, Del Río et al. (2014) revealed that silver fir was more affected by intra-specific than inter-specific competition, suggesting the presence of some degree of complementarity between European beech and silver fir. Bošela et al. (2015) noted that the growth of silver fir was positively influenced by admixture with European beech, showing facilitating effect or a reduction in competition of European beech on silver fir. Evidence of inter-specific facilitation or reduction in treeto-tree competition could be linked to differences in functional traits and phenological patterns of silver fir vs. European beech (Del Río et al. 2014). For example, compartmentalization of resource utilization may allow a different strategy for root water uptake (Lebourgeois et al. 2013). Complementary crown architectures and contrasting physiological adaptations may facilitate canopy expansion (European beech) and improve crown light interception in spring and autumn (silver fir - Lu et al. 2016). This suggests that, in mixed-species stands, tree species with complementary traits may increase the exploitation of resources in comparison with those species with similar traits (Pretzsch \& Schütze 2016). Ac- cording to Pretzsch \& Schütze (2016), improved resource use efficiency (e.g., light, water and nutrients) in mixed-species stands is attained when a complex vertical structure (small and large individuals of both species) occurs. In our case, the absence of inter-specific interactions $\left(\mathrm{Cl}_{2011}\right.$ inter) can be related to the smaller diameter in European beech than in silver fir, in the mixed-species stands of Molise and Calabria (Fig. 3). These differences between European beech and silver fir were also observed for the variation in tree height, silver fir being taller than European beech (Fig. S2 in Supplementary material). Therefore, the sub-dominant structural position of European beech within mixed-species stands may determine a reduction in competition for silver fir.

Overall, forest management that promotes multi-layered uneven-sized species mixtures might allow maintaining these Mediterranean mountain forests continuously, increasing their resilience and productivity. Although the importance of species mixture is recognized, management of mixed-species uneven-aged forests at the range edge of species distribution needs to be optimized for effective application. Indeed, the sustainability of species mixture might become an issue in drought-prone environments (Conte et al. 2018), in which a stable species distribution could be negatively affected by increasing disturbance frequency and intensity. For a continuous delivery of ecosystem services of mixedspecies mountain forests, the selective felling might regulate the occupation of the growing space of the species and enhance the development of the stands towards a multi-layered structure, making them more stable against natural hazards and ensuring the protective functions of the forests, for soils and biodiversity, as well as the maintenance of carbon stocks.

\section{Conclusion}

The growth models showed that intraspecific interactions influenced the basal area increment more than inter-specific interactions. In particular, intra-specific interactions negatively influenced the basal area increment of European beech and silver fir, both in pure and mixed-species stands of Molise and Calabria. In accordance with our first hypothesis, higher intra-specific interactions were observed in pure stands of both species than in corresponding mixed-species stands. Silver fir showed relatively lower levels of intra-specific competition, with higher basal area increment in mixed-species stands. This higher basal area increment of individual trees in mixed-species stands can be explained by the distinct stand structure, which may have increased space occupation and improved resource utilization. For European beech, high values of intra-specific interactions could be linked to its low self-tolerance and to the spatial arrangement of trees within the stands, following 
canopy closure. The absence of inter-specific interactions in mixed-species stands was probably related to the sub-dominant position of European beech, which may have reduced the benefit derived from niche separation and complementarity for silver fir. These results support our second hypothesis, providing useful insights on the structural and functional dynamics that occur in uneven-aged mixed-species forests vs. pure stands of European beech and silver fir. This suggest that mixtures of European beech and silver fir, a natural species combination in mountain regions, should be promoted as an option for mountain ranges in southern Europe. However, further studies with a larger number of samples are needed to draw more definitive conclusions, so as to help evaluate forest adaptation measures under global change scenarios.

\section{Acknowledgements}

The authors are grateful to Carabinieri Forestali of Petilia Policastro (KR, Italy) for their help in selecting the study sites. This study generated from the COST (European Cooperation in Science and Technology) Action CLIMO ("Climate-Smart Forestry in Mountain Regions" - CA15226) financially supported by the EU Framework Programme for Research and Innovation HORIZON 2020.

\section{References}

Ammer C (2019). Diversity and forest productivity in a changing climate. New Phytologist 221 (1): 50-66. - doi: 10.1111/nph.15263

Antonucci S, Rossi S, Lombardi F, Marchetti M, Tognetti R (2019). Influence of climatic factors on silver fir xylogenesis along the Italian Peninsula. IAWA journal 40 (2): 259-275. - doi: 10.1163/22941932-40190222

Aussenac R, Bergeron Y, Gravel D, Drobyshev I (2019). Interactions among trees: a key element in the stabilising effect of species diversity on forest growth. Functional Ecology 33 (2): 360-367. - doi: 10.1111/1365-2435.13257

Barton K (2013). MuMln: multi-model inference. R Package Version 1.9.5. [online] URL: https:// cran.r-project.org/web/packages/MuMIn/MuMI n.pdf

Bates D, Maechler M, Bolker B, Walker S (2014). Ime4: Linear mixed-effects models using Eigen and S4. R package version 1: 1-23. [online] URL: http://arxiv.org/abs/1406.5823

Biging GS, Dobbertin M (1992). A comparison of distance-dependent competition measures for height and basal area growth of individual conifer trees. Forest Science 38 (3): 695-720. [online] URL: http://academic.oup.com/forest science/article-abstract/38/3/695/4642125

Biging GS, Dobbertin M (1995). Evaluation of competition indices in individual tree growth models. Forest Science 41 (2): 360-377. [online] URL: http://academic.oup.com/forestscience/ar ticle-abstract/41/2/360/4627255

Biondi F (1999). Comparing tree-ring chronologies and repeated timber inventories as forest monitoring tools. Ecological Application 9 (1): 216-227. - doi: 10.1890/1051-0761(1999)009[0216:
CTRCAR]2.0.CO;2

Bošela $M$, Petráš $R$, Sitková $Z$, Priwitzer T, Pajtík J, Hlavatá H, Sedmák R, Tobin B (2014). Possible causes of the recent rapid increase in the radial increment of silver fir in the Western Carpathians. Environmental Pollution 184: 211-221. - doi: 10.1016/j.envpol.2013.08.036

Bošela $M$, Tobin $B$, Seben V, Petráš R, Larocque $G R$ (2015). Different mixtures of Norway spruce, silver fir, and European beech modify competitive interactions in central European mature mixed forests. Canadian Journal of Forest Research 45 (11): 1577-1586. - doi: 10.1139/ cjfr-2015-0219

Brassard BW, Chen HY, Cavard X, Laganière J, Reich PB, Bergeron Y, Paré D, Yuan Z (2013). Tree species diversity increases fine root productivity through increased soil volume filling. Journal of Ecology 101 (1): 210-219. - doi: 10.1111/ 1365-2745.12023

Brooker RW (2006). Plant-plant interactions and environmental change. New Phytologist 171 (2): 271-284. - doi: 10.1111/j.1469-8137.2006.01752.x

Coates KD, Lilles EB, Astrup R (2013). Competitive interactions across a soil fertility gradient in a multispecies forest. Journal of Ecology 101 (3): 806-818. - doi: 10.1111/1365-2745.12072

Condés S, Del Río M, Sterba H (2013). Mixing effect on volume growth of Fagus sylvatica and Pinus sylvestris is modulated by stand density. Forest of Ecology and Management 292: 86-95. - doi: 10.1016/j.foreco.2012.12.013

Conte E, Lombardi F, Battipaglia G, Palombo C, Altieri S, La Porta N, Marchetti M, Tognetti R (2018). Growth dynamics, climate sensitivity and water use efficiency in pure vs. mixed pine and beech stands in Trentino (Italy). Forest of Ecology and Management 409: 707-718. - doi: 10.1016/j.foreco.2017.12.011

Daniels RF (1976). Simple competition indices and their correlation with annual loblolly pine tree growth. Forest Science 22 (4): 454-456. [online] URL: http://academic.oup.com/forest science/article-abstract/22/4/454/4675851

Daniels RF, Burkhart HE, Clason TR (1986). A comparison of competition measures for predicting growth of loblolly pine trees. Canadian Journal of Forest Research 16 (6): 1230-1237. doi: $10.1139 / \times 86-218$

Del Río M, Condés S, Pretzsch H (2014). Analyzing size-symmetric vs. size-asymmetric and intra-vs. inter-specific competition in beech ( $\mathrm{Fa}$ gus sylvatica L.) mixed stands. Forest of Ecology and Management 325: 90-98. - doi: 10.1016/ j.foreco.2014.03.047

Dormann CF, Elith J, Bacher S, Buchmann C, Carl G, Carré G, García Marquéz JR, Gruber B, Lafourcade B, Leitão PJ, Münkemüller T, McClean C, Osborne PE, Reineking B, SchröDer B, Skidmore AK, Zurell D, Lautenbach S (2013). Collinearity: a review of methods to deal with it and a simulation study evaluating their performance. Ecography 36 (1): 27-46. - doi: 10.1111/ j.1600-0587.2012.07348.x

Forrester DI, Vanclay JK, Forrester RI (2011). The balance between facilitation and competition in mixtures of Eucalyptus and Acacia changes as stands develop. Oecologia 166 (1): 265-272. doi: 10.1007/s00442-011-1937-9

Forrester DI (2014). The spatial and temporal dynamics of species interactions in mixed-species forests: from pattern to process. Forest of Ecology and Management 312: 282-292. - doi: 10.101 6/j.foreco.2013.10.003

Forrester DI, Albrecht AT (2014). Light absorption and light-use efficiency in mixtures of Abies alba and Picea abies along a productivity gradient. Forest of Ecology and Management 328: 94-102. - doi: 10.1016/j.foreco.2014.05.026 Forrester DI, Bauhus J (2016). A review of processes behind diversity productivity relationships in forests. Current Forestry Reports 2 (1): 4-61. - doi: 10.1007/s40725-016-0031-2

Fox J, Weisberg S, Adler D, Bates D, Baud-Bovy G, Ellison S, Firth D, Friendly M. Gorjanc G, Graves S (2012). Package "car". R Foundation for Statistical Computing, Vienna, Austria. [online] URL: http://cran.r-project.org/web/packa ges/car/car.pdf

Fraver S, D'Amato AW, Bradford JB, Jonsson BG, Jönsson M, Esseen PA (2014). Tree growth and competition in an old-growth Picea abies forest of boreal Sweden: influence of tree spatial patterning. Journal of Vegetation Science 25 (2): 374-385. - doi: 10.1111/jvs.12096

Gamfeldt L, Snäll T, Bagchi R, Jonsson M, Gustafsson L, Kjellander P, Riuz-Jaen MC, Fröberg $M$, Stendahl J, Philipson CD, Mikusinski G, Andersson $E$, Westerlund $B$, Andrén $H$, Moen J, Bengtsson J (2013). Higher levels of multiple ecosystem services are found in forests with more tree species. Nature Communications 4 (1): 59. - doi: 10.1038/ncomms2328

Gazol A, Camarero J, Gomez-Aparicio JL (2016). Functional diversity enhances silver fir growth resilience to an extreme drought. Journal of Ecology 104: 1063-1075. - doi: 10.1111/1365-2745.1 2575

Grissino-Mayer HD (2001). Evaluating crossdating accuracy: a manual and tutorial for the computer program COFECHA. Tree Ring Research 57: 205-221. [online] URL: http://hdl.handle.net/ 10150/251654

Grossiord C, Granier A, Ratcliffe S, Bouriaud O, Bruelheide $\mathrm{H}$, Chećko E, Forrester DI, Dawud $S M$, Finér L, Pollastrini $M$, Scherer-Lorenzen $M$, Valladares F, Bonal D, Gessler A (2014). Tree diversity does not always improve resistance of forest ecosystems to drought. Proceedings of the National Academy of Sciences USA 111 (41): 14812-14815. - doi: 10.1073/pnas.1411970111 Hegyi $F$ (1974). A simulation model for managing jack-pine stands simulation (Fries J ed). Royal College of Forestry, Stockholm, Sweden, pp. 74-90.

Holmes RL, Adams RK, Fritts HC (1986). Tree-ring chronologies of western North America: California, eastern Oregon and northern Great Basin with procedures used in the chronology development work including users manuals for computer programs COFECHA and ARSTAN. Chronology Series VI, University of Arizona, Tucson, AZ, pp. 185. [online] URL: http://hdl. handle.net/10150/304672

Jactel H, Brockerhoff EG (2007). Tree diversity reduces herbivory by forest insects. Ecology Letters 10 (9): 835-848. - doi: 10.1111/j.14610248.2007.01073.x

Klein T (2014). The variability of stomatal sensitivity to leaf water potential across tree species indicates a continuum between isohydric and anisohydric behaviours. Functional Ecology 28: 
1313-1320. - doi: 10.1111/1365-2435.12289

Lebourgeois F, Gomez N, Pinto P, Mérian P (2013). Mixed stands reduce Abies alba treering sensitivity to summer drought in the Vos ges mountains, western Europe. Forest of Ecology and Management 303: 61-71. - doi: 10.1016/j. forec0.2013.04.003

Liang J, Crowther TW, Picard N, Zhou M, Albert G, Schulze E-D, McGuire AD, Bozzato F, Pret zsch $\mathrm{H}$, De-Miguel $\mathrm{S}$, Paquette $A$, Hérault $B$ Scherer-Lorenzen M, Barrett CB, Glick HB, Hengeveld GM, Nabburs G-J, Pfautsch S, Viana $H$, Vibrans AC, Ammer C, Schall P, Verbyla D, Tchebakova N, Fischer M, Watson JV, Chen HYH, Lei X, Schelhaas M-J, Lu H, Gianelle D, Parfenova El, Salas C, Lee E, Lee B, Kim HS, Bruelheide $\mathrm{H}$, Coomes DA, Piotto D, Sunderland $T$, Schmid B, Gourlet-Fleury S, Sonké B, Tavani R, Zhu J, Brandl S, Vayreda J, Kitahara F, Searle EB, Neldner VJ, Ngugi MR, Baraloto C, Frizzera L, Balazy R, Oleksyn J, Zawila-Niedzwiecki T, Bouriaud $O$, Bussotti F, Finér L, Jaroszewicz $B$, Jucker T, Valladares F, Jagodzinski AM, Peri PL, Gonmadje C, Marthy W, O’Brien T, Martin EH, Marshall AR, Rovero F, Bitariho R, Niklaus PA, Alvarez-Loayza P, Chamuya N, Valencia R, Mortier F, Wortel V, Engone-Obiang NL, Ferreira LV, Odeke DE, Vasquez RM, Lewis SL, Reich PB (2016). Positive biodiversity-productivity relationship predominant in global forests. Science 354 (6309): aaf8957. - doi: 10.1126/science.aaf 8957

Linares JC, Camarero JJ, Carreira JA (2010). Competition modulates the adaptation capacity of forests to climatic stress: insights from recent growth decline and death in relict stands of the Mediterranean fir Abies pinsapo. Journal of Ecology 98 (3): 592-603. - doi: 10.1111/j.1365-2745.20 10.01645.x

Lorimer CG, Dahir SE, Nordheim EV (2001). Tree mortality rates and longevity in mature and oldgrowth hemlock-hardwood forests. Journal of Ecology 89 (6): 960-971. - doi: 10.1111/j.1365-274 5.2001.00619.x

Lu H, Mohren GM, Den Ouden J, Goudiaby V, Sterck FJ (2016). Overyielding of temperate mixed forests occurs in evergreen-deciduous but not in deciduous-deciduous species mixtures over time in the Netherlands. Forest of Ecology and Management 376: 321-332. - doi: 10.1016/j.foreco.2016.06.032

Magh RK, Bonn B, Grote R, Burzlaff T, Pfautsch $S$, Rennenberg H (2019). Drought superimposes the positive effect of silver fir on water relations of European beech in mature forest stands. Forests 10 (10): 897. - doi: 10.3390/f1010 0897

Martin GL, Ek AR (1984). A comparison of competition measures and growth models for predicting plantation red pine diameter and height growth. Forest Science 30 (3): 731-743. [online] URL: http://academic.oup.com/forestscience/ar ticle-abstract/30/3/731/4656929

Marziliano PA, Tognetti R, Lombardi F (2019). Is tree age or tree size reducing height increment in Abies alba Mill. at its southernmost distribution limit? Annals of Forest Science 76: 17. - doi: 10.1007/s13595-019-0803-5

Metz J, Seidel D, Schall P, Scheffer D, Schulze ED, Ammer C (2013). Crown modeling by terrestrial laser scanning as an approach to assess the ef- fect of aboveground intra-and interspecific competition on tree growth. Forest of Ecology and Management 310: 275-288. - doi: 10.1016/j. foreco.2013.08.014

Mina $M$, Huber MO, Forrester DI, Thürig $E$, Rohner B (2018a). Multiple factors modulate tree growth complementarity in central European mixed forests. Journal of Ecology 106 (3): 1106-1119. - doi: 10.1111/1365-2745.12846

Mina M, Del Río M, Huber MO, Thürig E, Rohner $B$ (2018b). The symmetry of competitive interactions in mixed Norway spruce, silver fir and European beech forests. Journal of Vegetation Science 29 (4): 775-787. - doi: 10.1111/jvs.12664

Mölder I, Leuschner C (2014). European beech grows better and is less drought sensitive in mixed than in pure stands: tree neighbourhood effects on radial increment. Trees 28 (3): 777792. - doi: 10.1007/s00468-014-0991-4

Pinheiro JC, Bates DM (2000). Statistics and computing. Mixed-effects models in S and SPLUS Statistics and Computing book series, Springer-Verlag, New York, USA, pp. 3-56. - doi: 10.1007/0-387-22747-4_1

Pretzsch H (2006). Species-specific allometric scaling under self-thinning: evidence from longterm plots in forest stands. Oecologia 146 (4): 572-583. - doi: 10.1007/s00442-005-0126-0 Pretzsch H, Schütze G (2009). Transgressive overyielding in mixed compared with pure stands of Norway spruce and European beech in Central Europe: evidence on stand level and explanation on individual tree level. European Journal of Forest Research 128 (2): 183-204. doi: 10.1007/s10342-008-0215-9

Pretzsch H, Block J, Dieler J, Dong PH, Kohnle U, Nagel J, Spellmann H, Zingg A (2010). Comparison between the productivity of pure and mixed stands of Norway spruce and European beech along an ecological gradient. Annals of Forest Science 67 (7): 712. - doi: 10.1051/forest/ 2010037

Pretzsch H, Matthew C, Dieler J (2012). Allometry of tree crown structure. Relevance for space occupation at the individual plant level and for self-thinning at the stand level. In: "Growth and Defence in Plants". Springer, Berlin, Heidelberg, Germany, pp. 287-310. - doi: 10.1007/978-3-642-30645-7_13

Pretzsch H, Schütze G, Uhl E (2013). Resistance of European tree species to drought stress in mixed versus pure forests: evidence of stress release by inter-specific facilitation. Plant Biology 15: 483-495. - doi: 10.1111/j.1438-8677.2012.0 0670.x

Pretzsch H (2014). Canopy space filling and tree crown morphology in mixed-species stands compared with monocultures. Forest Ecology and Management 327: 251-264. - doi: 10.1016/j. foreco.2014.04.027

Pretzsch H, Biber P, Schütze G, Bielak K (2014). Changes of forest stand dynamics in Europe. Facts from long-term observational plots and their relevance for forest ecology and management. Forest Ecology and Management 316: 6577. - doi: 10.1016/j.foreco.2013.07.050

Pretzsch H, Biber P (2016). Tree species mixing can increase maximum stand density. Canadian Journal of Forest Research 46 (10): 1179-1193. doi: 10.1139/cjfr-2015-0413

Pretzsch H, Schütze G (2016). Effect of tree spe- cies mixing on the size structure, density, and yield of forest stands. European Journal of Forest Research 135 (1): 1-22. - doi: 10.1007/s10342015-0913-Z

Rewald B, Leuschner C (2009). Belowground competition in a broad-leaved temperate mixed forest: pattern analysis and experiments in a four-species stand. European Journal of Forest Research 128 (4): 387-398. - doi: 10.1007/ s10342-009-0276-4

Rinn F (2003). TSAP-win. Time series analysis and presentation for dendrochronology and related applications. User Reference, Heidelberg, Germany. [online] URL: http://rinntech.info/prod ucts/tsap-win/

Rouvinen S, Kuuluvainen T (1997). Structure and asymmetry of tree crowns in relation to local competition in a natural mature Scots pine forest. Canadian Journal of Forest Research 27 (6): 890-902. - doi: 10.1139/x97-012

Schwarz JA, Bauhus J (2019). Benefits of mixtures on growth performance of silver fir (Abies alba) and European beech (Fagus sylvatica) increase with tree size without reducing drought tolerance. Frontiers in Forests and Global Change 2: 1483. - doi: 10.3389/ffgc.2019.0 0079

Seidl R, Spies TA, Peterson DL, Stephens SL, Hicke JA (2016). Searching for resilience: addressing the impacts of changing disturbance regimes on forest ecosystem services. Journal of Applied Ecology 53 (1): 120-129. - doi: 10.1111/136 5-2664.12511

Spies TA, Franklin JF, Klopsch M (1990). Canopy gaps in Douglas-fir forests of the Cascade Mountains. Canadian Journal of Forest Research 20 (5): 649-658. - doi: 10.1139/×90-087 Stadt KJ, Huston C, Coates KD, Feng Z, Dale MR, Lieffers VJ (2007). Evaluation of competition and light estimation indices for predicting diameter growth in mature boreal mixed forests. Annals of Forest Science 64 (5): 477-490. - doi: 10.1051/forest:2007025

Tognetti R, Cherubini P, Marchi S, Raschi A (2007). Leaf traits and tree rings suggest different water-use and carbon assimilation strategies by two co-occurring Quercus species in a Mediterranean mixed-forest stand in Tuscany, Italy. Tree Physiology 27: 1741-1751. - doi: 10.1093 /treephys/27.12.1741

Tielbörger K, Kadmon R (2000). Temporal environmental variation tips the balance between facilitation and interference in desert plants. Ecology 81 (6): 1544-1553. - doi: 10.1890/0012-96 58(2000)081[1544:TEVTTB]2.0.CO;2

Toïgo M, Vallet P, Perot T, Bontemps JD, Piedallu $C$, Courbaud B (2015). Overyielding in mixed forests decreases with site productivity. Journal of Ecology 103 (2): 502-512. - doi: 10.1111/1365-2745. 12353

Tomé M, Burkhart HE (1989). Distance-depen dent competition measures for predicting growth of individual trees. Forest Science 35 (3): 816-831. [online] URL: http://academic.oup. com/forestscience/article-abstract/35/3/816/464 2604

Vilà M, Carrillo-Gavilán A, Vayreda J, Bugmann H, Fridman J, Grodzki W, Haase J, Kunstler G, Schelhaas M, Trasobares A (2013). Disentangling biodiversity and climatic determinants of wood production. PLoS One 8(2): e53530. - doi: 
10.1371/journal.pone.0053530

Wang D, Tang SC, Hsieh HC, Chung $\mathrm{CH}$, Lin $\mathrm{CY}$ (2012). Distance-dependent competition measures for individual tree growth on a Taiwania plantation in the Liuguei area. Taiwan Journal of Forest Science 27: 215-227.

Weber P, Bugmann H, Fonti P, Rigling A (2008). Using a retrospective dynamic competition in dex to reconstruct forest succession. Forest of Ecology and Management 254 (1): 96-106. - doi: 10.1016/j.foreco.2007.07.031

Weiskittel AR, Hann DW, Kershaw JAJ, Vanclay JK (2011). Forest growth and yield modeling. John Wiley and Sons, Chichester, UK, pp. 344. [online] URL: http://books.google.com/books? id $=M J 4 \_S 8 s r X \times 4 C$

Wykoff WR (1990). A basal area increment model for individual conifers in the northern Rocky Mountains. Forest Science 36 (4): 10771104. [online] URL: http://academic.oup.com/ forestscience/article-abstract/36/4/1077/464270
Zuur A, leno EN, Walker N, Saveliev AA, Smith GM (2009). Mixed effects models and extensions in ecology with R. Statistics for Biology and Health, Springer Science and Business Media, New York, USA, pp. 574. [online] URL: http://books.google.com/books?id=vQUNprFZK $\mathrm{HsC}$

\section{Supplementary Material}

Appendix 1 - Additional information on the model selection.

Fig. S1 - Residuals vs. predicted log-transformed BAl of growth models in Tab. 4 and Tab. 5 .

Fig. S2 - Height of all European beech and silver fir trees.
Tab. S1 - Optimal search radii selected on the basis of the best values of linear regression models, considering all sampled trees.

Tab. S2 - Comparisons between different variables of silver fir mixed-pure in linear mixed models.

Tab. S3 - Comparisons between different variables of European beech mixed-pure in linear mixed models.

Tab. S4 - Parameter estimates for intra-specific interaction models fitted through the likelihood criterion (ML).

Tab. S5 - Parameter estimates for inter-specific interaction models fitted through the likelihood criterion (ML).

Link: Versace_3476@supploo1.pdf 